Document downloaded from:

http://hdl.handle.net/10251/176104

This paper must be cited as:

Rodríguez Navarro, P.; Gil Piqueras, T. (2020). New Contributions on the Escuelas Pías Dome in Valencia. Nexus Network Journal (Online). 22(4):1081-1098.

https://doi.org/10.1007/s00004-020-00500-5

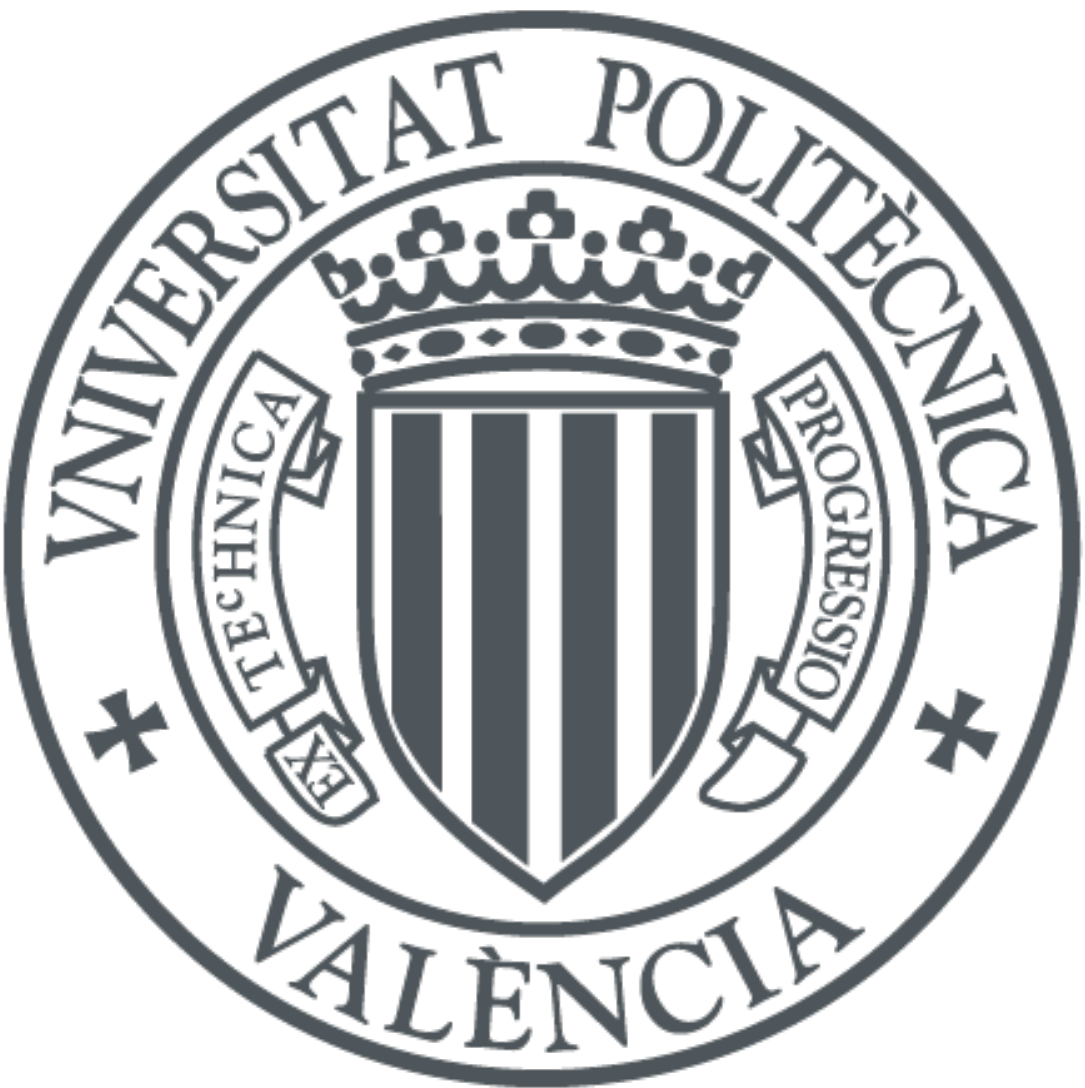

The final publication is available at

https://doi.org/10.1007/s00004-020-00500-5

Copyright Springer-Verlag

Additional Information 


\title{
New Contributions on the Escuelas Pías Dome in Valencia
}

\begin{abstract}
In the city of Valencia (Spain), domes covered by blue-glazed roofing tiles are common, but there is one that stands out above all others; the dome of the Escuelas Pías, one of the largest single-shell domes of Christianity. This dome is pending repair due to the appearance of large cracks. The present contribution aims to take us closer to the construction of the dome. By following a historical trajectory, we broaden its formal analysis providing a constructive approach that determines some factors on which some questions and controversies have been raised. Thus, we intend to solve these issues and others based on the results obtained from a high-precision graphic survey carried out by the authors. Based on the analysis of this graphic survey, new contributions regarding to its current morphology and the construction system used will be facilitated, revealing some unknowns that enable the understanding of its structural functioning and its constructive technology.
\end{abstract}

\section{Introduction}

The Escuelas Pías (Pious Schools) emerged at the end of the sixteenth century under the auspices of José de Calasanz, a pioneer of modern pedagogy and an advocate of the right to free education for all social classes, especially the neediest households. In 1597, when education was limited to the highest social classes, Calasanz founded the first free school in Europe, located in the old sacristy of the parish of Santa Dorotea, in Rome (Soler Blázquez 2017: 49). This school became known as the "Escuela Pía”, and a multitude of schools existing nowadays all over the world have adopted its name. The Escolapios (Piarists), name by which the religious of the Order of Poor Clerics Regular of the Mother of God of the Pious Schools are known, descendants of Calasanz's teachings, was initiated in Valencia in 1737 through the efforts of the fourth Count of Carlet, Felipe Lino de Castellví y Ximénez de Urrea Blasco, Climent, Manrique y Joan (Bérchez 1983: 492; Soler Blánquez 2017: 130,131), almost a hundred years after the death of Calasanz. Among the numerous educational projects of the Count of Carlet, the most successful one was the founding of the Escuelas Pías in Valencia.

Between 1739 and 1747, the convent and the school were built under the direction of the religious Blas del Espiritu Santo, architect of the Piarist order, beginning with the construction of the church twenty years after the school was finished.

\section{Church of the Escuelas Pías}

The Church of the Escuelas Pías of Valencia, also known as the Escolapios or San Joaquín (Corbín Ferrer 2001: 166), is located in one of the oldest neighbourhoods in the city, specifically, in the medieval historical district of velluters (velvet weavers), known by that name since the fifteenth century for being the neighbourhood of silk craftsmen within the Ciutat Vella (Old Town) district. The church stands attached to the east side of the school, occupying a 2,415.67 $\mathrm{m}^{2}$ plot, between the Calle de Colomer and Calle de los Carniceros. 
Its construction began in the second half of the eighteenth century, with Archbishop Andrés Mayoral de Mell, who promoted its construction. One of his requirements was to build a church that could be distinguished from those of the Valencian architectural tradition, so he commissioned the drawing up to various architects, including Fray Alberto Pina and José Puchol.

In 1767, the planning of the church began in earnest, with the project finally being awarded to Puchol. In his design, in accordance with the classic models, the church was conceived from a centralized geometric floorplan that housed ten small spaces separated by ten large brick buttresses, all covered by a large dome. The conception of the church follows the trend of the moment, as it can be seen in contemporary churches, such as that of the Augustinians in Valladolid initiated by Ventura Rodríguez in 1759 and the Royal Basilica of San Francisco el Grande in Madrid, designed by the Valencian architect Fray Francisco Cabezas and built between 1761 and 1784 .

A year after the construction works were initiated, Antonio Gilabert Fornés, until then a disciple of Puchol and from that moment on Director of Architecture of the newly inaugurated Real Academia de Bellas Artes de San Carlos, took control of the commission, rectifying the project in what refers to the interior of the temple, the façade and the bell tower (Bérchez 1983: 494). Despite this, José Puchol continued to be present, although his work became secondary. In 1769, after a one-year period in which the works were paralyzed due dwindling financial resources, the General Commission on the Crusades by order of King Carlos III approved the granting of the necessary funds for its conclusion, which took place in January 1771 (Bérchez 1983: 494), with a total cost of 787,400 real-coins and 18 maravedís de vellón (Cortés Meseguer 2018: 72). In April 1773, the church was consecrated for worship.

The church's ensemble, the convent and the school have been declared an Asset of Cultural Interest within the Historical Complex of the City of Valencia, according to Decree 57/1993 DOGV 10/05/19931, the dome being given integral protection.

\section{Formal Analysis}

The church was built next to the east side of the school, with its main façade on Calle de los Carniceros. Inside, the church is distributed in three tiers of different heights, from the ground to the starting of the dome. Apparently, both the design of its structure and the first tier are due to Puchol, while the rest is attributed to Gilabert (Bérchez 1983: 495). Given its formal and constructive characteristics, we can state that this church is an outstanding example of the neoclassical religious architecture of the time (Montoliu Soler 1983: 356) considering its dome as a maximum example of the brick domes (rigged domes) of typical construction in Valencia (Soler Verdú and Soler Estrela 2015). 

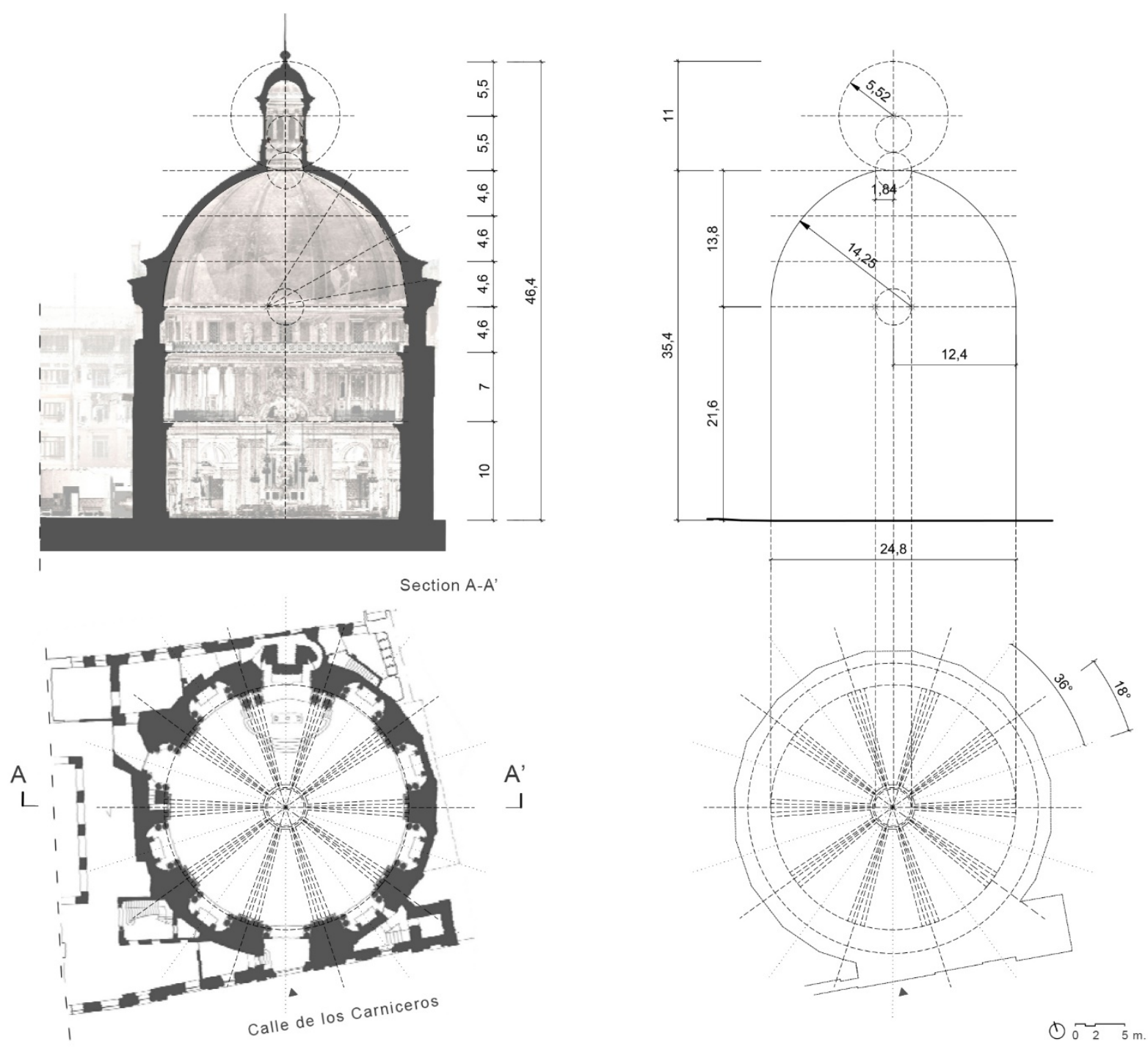

C) $\lcm{2} 5 \mathrm{~m}$

Fig. 1 Floorplan and section of the church, with a geometric scheme of the development of the dome. Images: Rodríguez-Navarro \& Gil-Piqueras

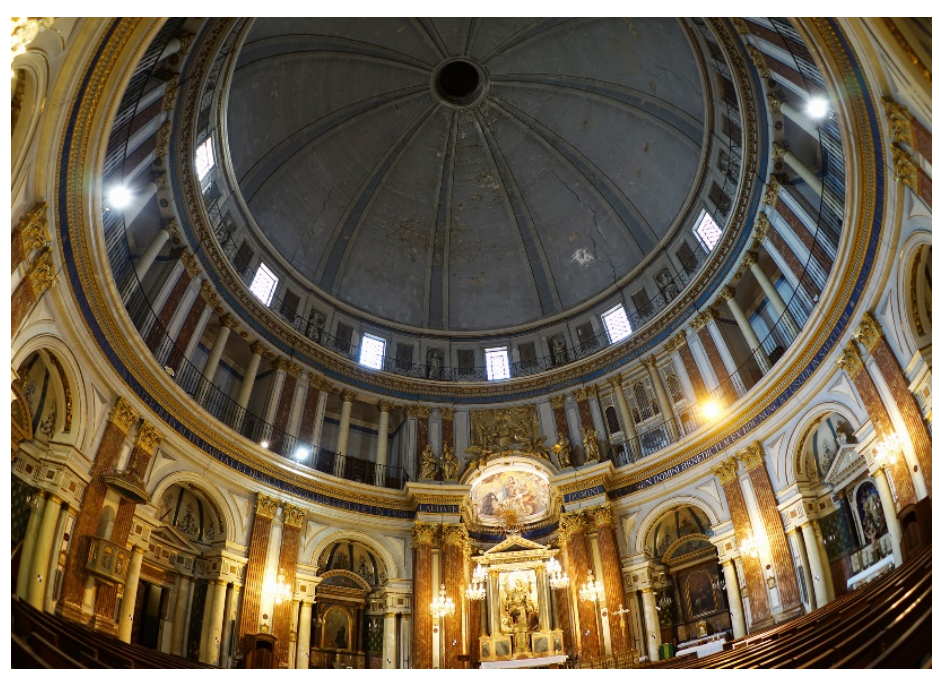

Fig. 2 Interior of the church where the three tiers that compose it may be observed, crowned by the great dome. Image: Rodríguez-Navarro \& Gil-Piqueras 
At the entrance to the church we find an atrium. Once inside, we can observe the circular plan, on whose perimeter its walls rise (Figs. 1, 2). The first tier, located in the lower part, has a height of $10.00 \mathrm{~m}$. to the top of the first cornice. Its inner perimeter is divided into ten spaces (among which are the atrium and an altar) separated by ten buttresses of solid brick, arising alternately from twenty axes which are repeated every $18^{\circ}$, radially and from the centre of the church. The alignment that passes through the centre of the atrium and the altar, located just opposite, connects with Calle de los Carniceros. From it, the inner sidewalls of the church are divided by alternating solid areas with small exedras, four on the right side and four on the left, with an access to the interior of the school through one of them. The exedras, mostly destined to chapels, as well as the altar and the atrium, are delimited on their sides by Doric-style intercolumniation, following the Palladian motif. At the same time, each of the buttresses presents, attached to their intrados, a pair of pilasters with a fluted shaft and a Corinthian capital, which in the case of the altar are preceded by two columns separated from the wall, reminiscent of late-Baroque decorations observed in Guarino Guarini’s Piedmontese architecture (Bérchez 1983: 497; Spallone and Vitali 2017). From the first chapel located to the right of the main entrance, an inner staircase leads us to the upper part of the church and to the bell tower. Topping this first tier we find a large cornice on which rests a metal railing marking the limit of the next tier.

The second tier is smaller than the first, reaching a total height of $7.00 \mathrm{~m}$. to the upper face of the second cornice. It follows the same layout defined on the lower floor, except that in this case the open areas are topped by a flat lintel supported by two columns, arranged at 1/4 of the span between buttresses, which transfer their loads to the small semi-circular apses that finish off the lower chapels. At this tier, both the columns exempt from the voids and the pilasters attached to the buttresses are topped by a Corinthian-style capital. Again, a great cornice separates it from the next tier. Unlike in the lower level, in some cases, in this storey, the buttresses do not cover the entire thickness of the wall, leaving a kind of ambulatory at the rear, an unobstructed passage about $80 \mathrm{~cm}$ wide, and on the inner side a corridor of the same dimensions, which acts as a tribune.

The third and final tier has a height of $4.60 \mathrm{~m}$, much lower than the previous ones, possibly attributed to the financial problems and the budget cuts that characterized the end of the works (Bérchez 1983: 495). Keeping up with the same scheme used in the lower levels consisting of buttresses and voids, this storey displays, in the axis of its buttresses, small niches where the images of the apostles are housed. On both sides of these recesses, we can find some paintings framed by a rectangular moulding. Then, and located on the axis of the lower chapels, some voids currently closed by glass are opened to the outside allowing the sunlight penetrate the interior of the church. The cornice topping this last tier gives way to the impost of the dome.

In general, we may see that the interior of the church, up to the impost of the dome, is clearly inspired by Agrippa's Pantheon. In all three tiers, there are elements recalling the interior of the Pantheon, such as the elevation of the cornice on the altar and the atrium, highlighting them over the rest by pronouncing their height; the flat lintels between buttresses supported by Corinthian columns, which may be observed on the second floor of the church; or the rectangular panels alternated with recesses in the third tier. 
Similarly, following the trends of ancient centralized plan buildings, beneath the main church is a crypt formed by three domed spaces that served as mausoleum for illustrious members of the Order (Fig. 3a). Of the three rooms, two of them are connected and are accessible through a staircase that comes down from the ground level, through a trapdoor located in front of the access that communicates with the school, while the third room, independent of the previous ones, can only be accessed by a ladder through an entry located near the centre of the church (Fig. 3b).
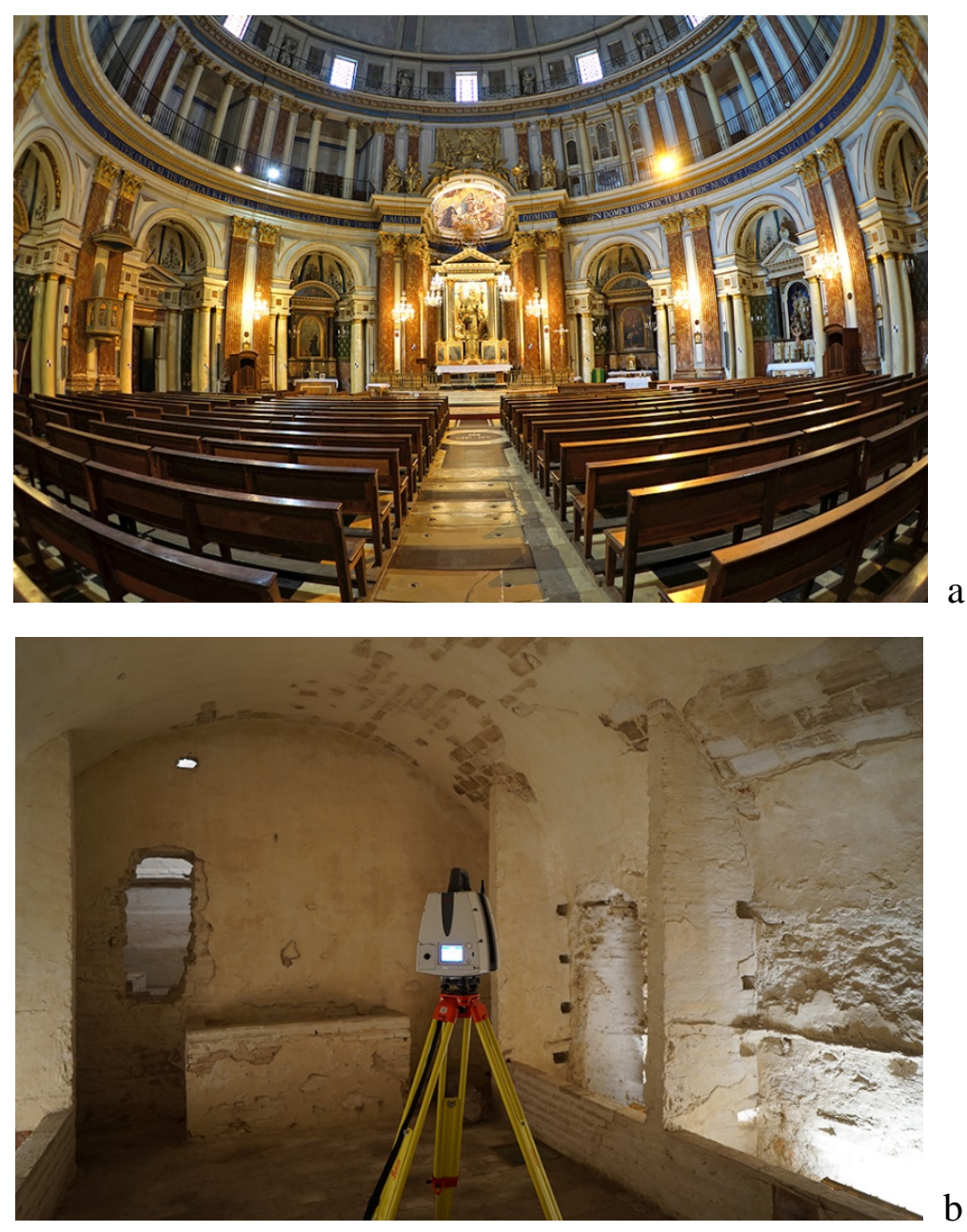

Fig. 3 a) Interior of the church with the main altar at the back; b) Crypt scanning phase. Images: Rodríguez-Navarro \& Gil-Piqueras

The church is covered by a large dome, externally lined with glazed-blue roofing tile, very characteristic of the Valencian constructive tradition.

\section{The Great Blue Dome}

The dome covers the interior surface of the church, generating a unique and centralized inner space. Contrary to what it has been stated (Bérchez 1983: 494; Soler Verdú 1996: 1), our research supports the idea that it is not a hemispherical dome, but it rather has a slightly cambered morphology (Fig. 4). Considering its start over the horizontal of the last cornice of the drum, located at a height of $21.60 \mathrm{~m}$. from the ground, we obtain a dome radius of $12.40 \mathrm{~m}$. at the buttresses, while the height from that alignment to the base of the lantern is $13.80 \mathrm{~m}$. To 
find this oval shape in height of the dome over a circular plan is hardly surprising, since Benito Bails already recommended it in order to avoid the optical effect that would make it appear flattened (Bails 1796: 846).

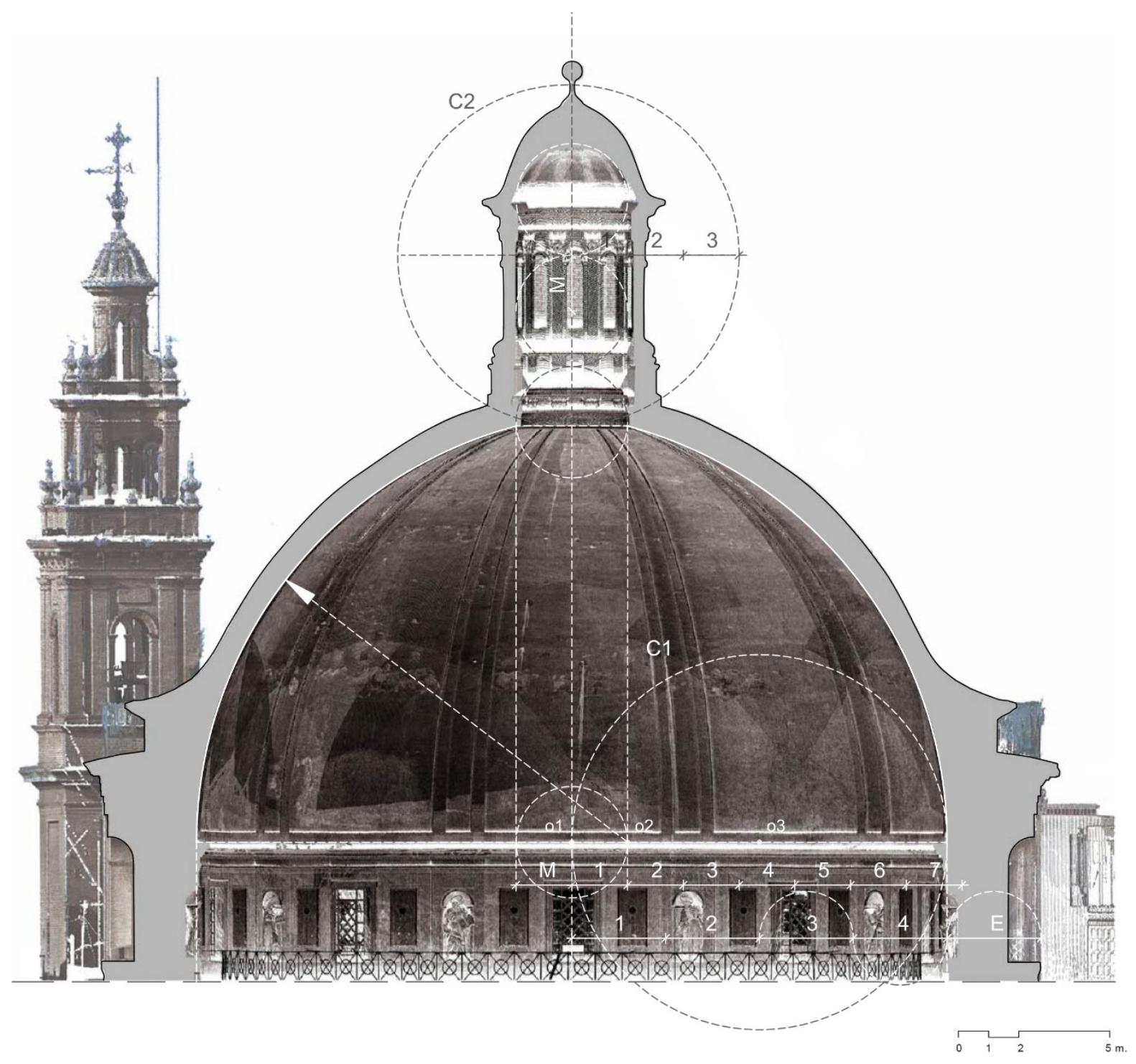

Fig. 4 Geometric development of the layout of the Escuelas Pías dome. Source: Rodríguez-Navarro \& Gil-Piqueras

Similarly, analysing the geometry of the dome and its lantern (Fig. 4) we have been able to verify that its layout follows the patterns established by Carlo Fontana (1694: 399, 401) in his work Il Tempio Vaticano e sua origine, in which he exposes the geometric canons of a single-shell dome and its lantern, represented through static analysis (Huerta 2007).

When analysing the geometric construction of the model in depth, we can see some discrepancies between the proportions in the lantern and the dome and those described in the source (Fig. 5). 

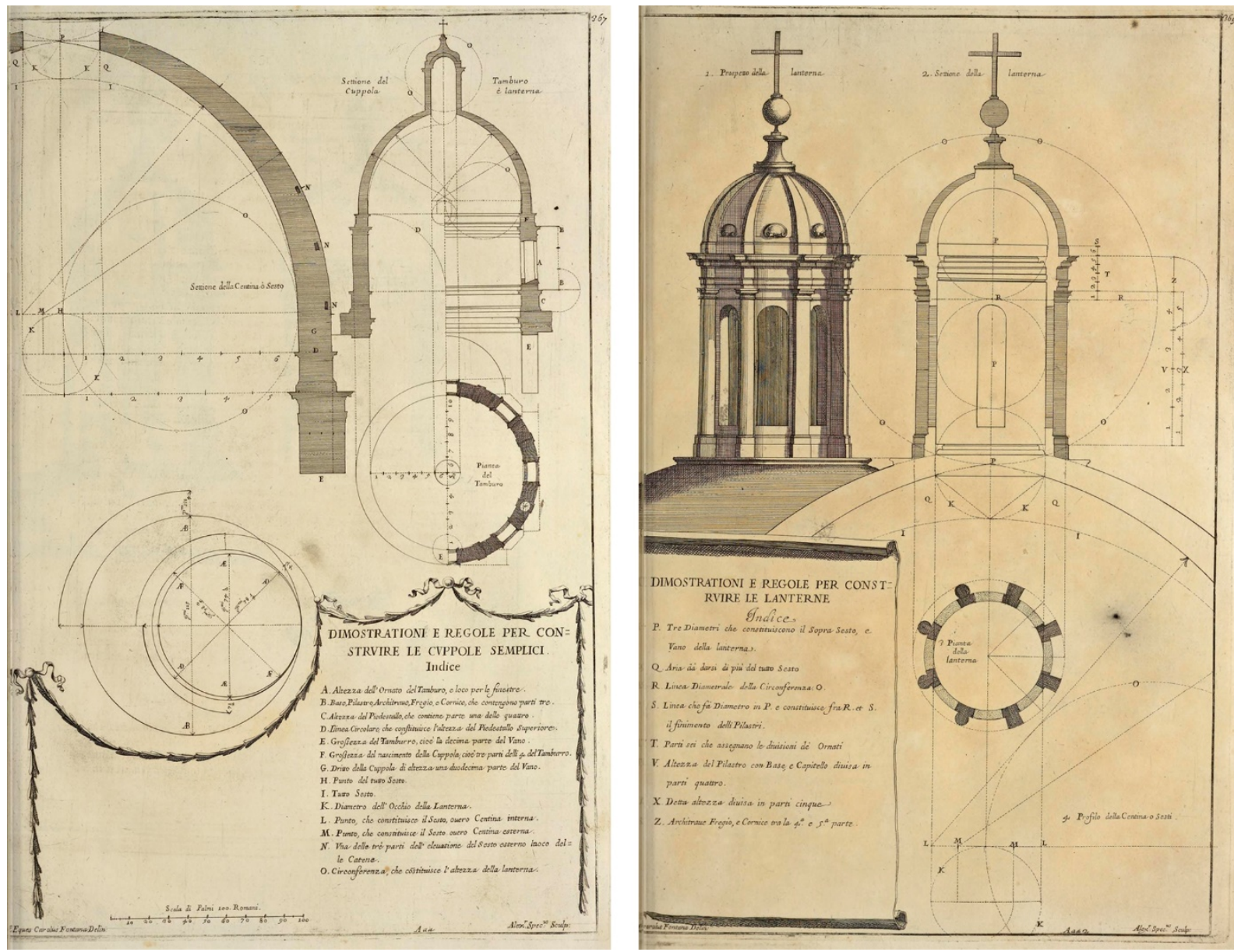

Fig. 5 Design and static analysis for the construction of a single-shell dome and its lantern made by Fontana. Source: (Fontana 1694: 367 (left); 369 (right)

While in the Fontana model, the radius of the lantern hollow is the modulus (M) that determines the lantern height (6M) and the dome diameter (12M), in the case of the Escuelas Pías, this relationship is only maintained between the radius of the lantern and its height, since the dome has a larger diameter (13.5 times $\mathrm{M})$.

Regarding the relationship between the internal diameter of the dome and the thickness of the drum wall (E), we can also notice that, in the case of the Escuelas Pías, this relationship is $8 \mathrm{E}$, while in the Fontana model this proportion is $10 \mathrm{E}$.

Finally, with respect to the intrados centre of the dome, in the case of Fontana, it is at a height of $\mathrm{M}$ from the starting plane (point L), while, in the case of the Escuelas Pías, the dome centre is located on the same starting plane.

Everything indicates that, although the geometric model of the dome of the Escuelas Pías follows the geometric layout of Fontana, the proportional relationships between the parts differ somewhat.

The interior of the dome is divided into ten sectors, separated by ten meridian mouldings, originating at their base at the level of the drum niches, while their upper ends are joined in a small moulding that surrounds the oculus. The inner surface of the dome has no representational paintings, possibly due to the financial problems that affected the end of the works (Bérchez 
1983: 494). Crowning the dome we find the lantern, following the same pattern that is repeated constantly throughout the church, that is, dividing its perimeter into 10 openings to the exterior-currently blinded as a result of the last intervention-separated by 10 solid brick pilasters decorated with mouldings and topped by a brick frieze on which the eave of the covering rests. The lantern is covered with a small brick dome, covered with blue-glazed tiles, as is the dome, its 10 sectors separated from each other by a row of white tiles as meridian lines. From the ground to the oculus where the lantern rests there is a total height of $35.40 \mathrm{~m}$., the church having a total height to the top of the lantern's dome of $46.40 \mathrm{~m}$.

On the outside, the dome has a different appearance. A brick wall of approximately $7 \mathrm{~m}$. closes the part corresponding to the third tier or drum on the outside, creating an offset of proportions between the inner and outer height, which in the case of the windows is resolved by splaying the upper part of the openings (Fig. 7). In this part, the enclosure follows a constant rhythm generated from 20 flat surfaces, in which the opening of the voids alternate with niches, similar to those found in the interior, but of greater dimensions. Over this tier, approximately $1.50 \mathrm{~m}$ high from its outer limit, rests another $1 \mathrm{~m}$ high small enclosure, which finally supports the dome.

Both the eave generated between the two exterior enclosures and the dome are topped with blue-glazed roofing tiles. In the case of the dome, the tiles follow the same decorative motif as in the interior, by dividing its surface into 10 sectors, each delimited by a double alignment of white roofing tiles repeating the interior's decoration.

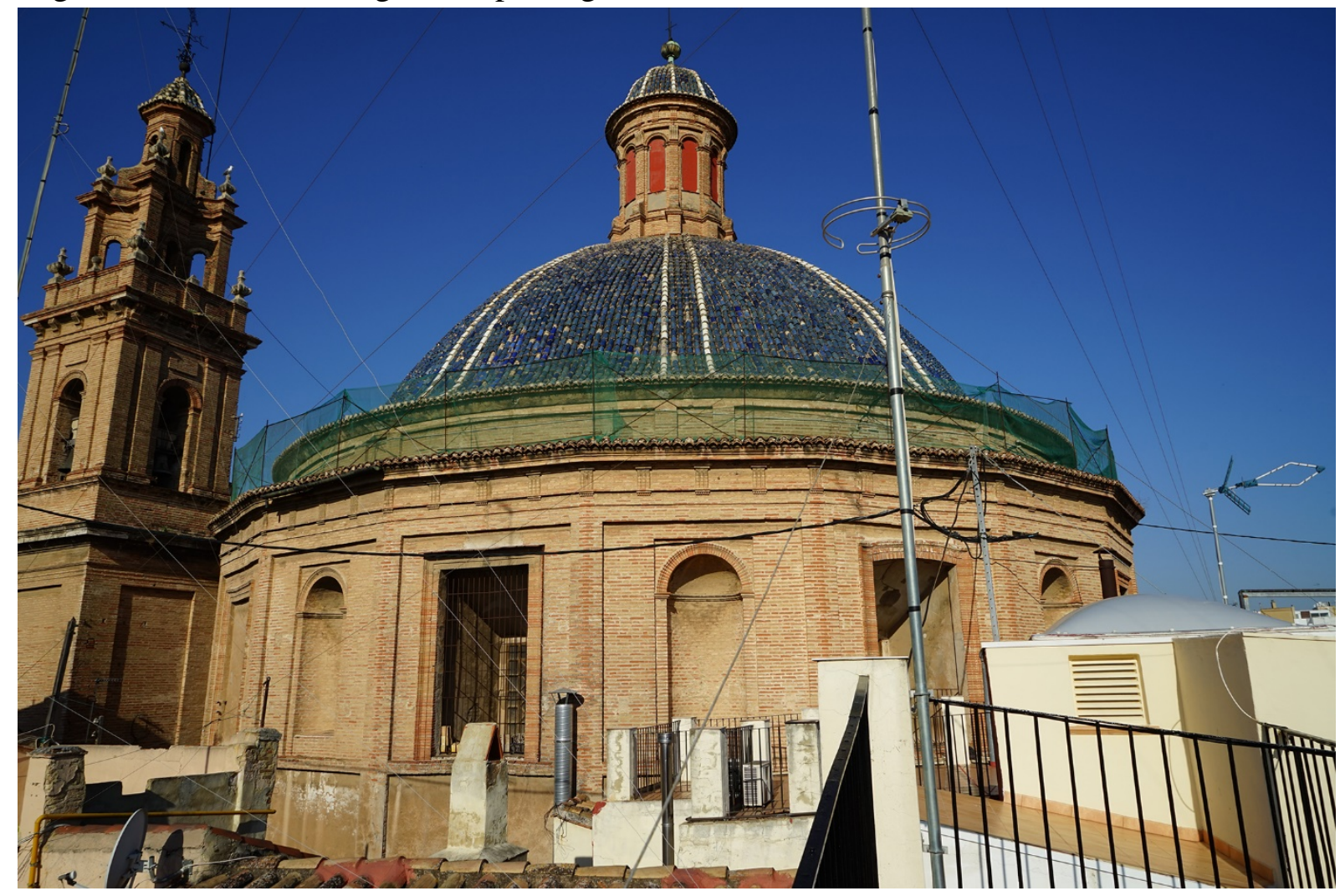

Fig. 6 Exterior of the dome where splayed openings and outside niches can be observed. Source: Rodríguez-Navarro \& Gil-Piqueras 
The Escuelas Pías dome is the largest of the Valencian Community domes constructed in brick. Due to its large dimensions, it must have had a great impact on the Valencian society of the time, appearing quickly delineated in the plans that are made at the beginning of the nineteenth century of the city of Valencia, as we see in the Plano geométrico de la Ciudad de Valencia llamada del Cid by Francisco Ferrer (1831) (Fig. 7), an academic from the Real Academia de Bellas Artes de San Carlos, in which the dome is graphically represented in a circle, something that is not seen in other instances.

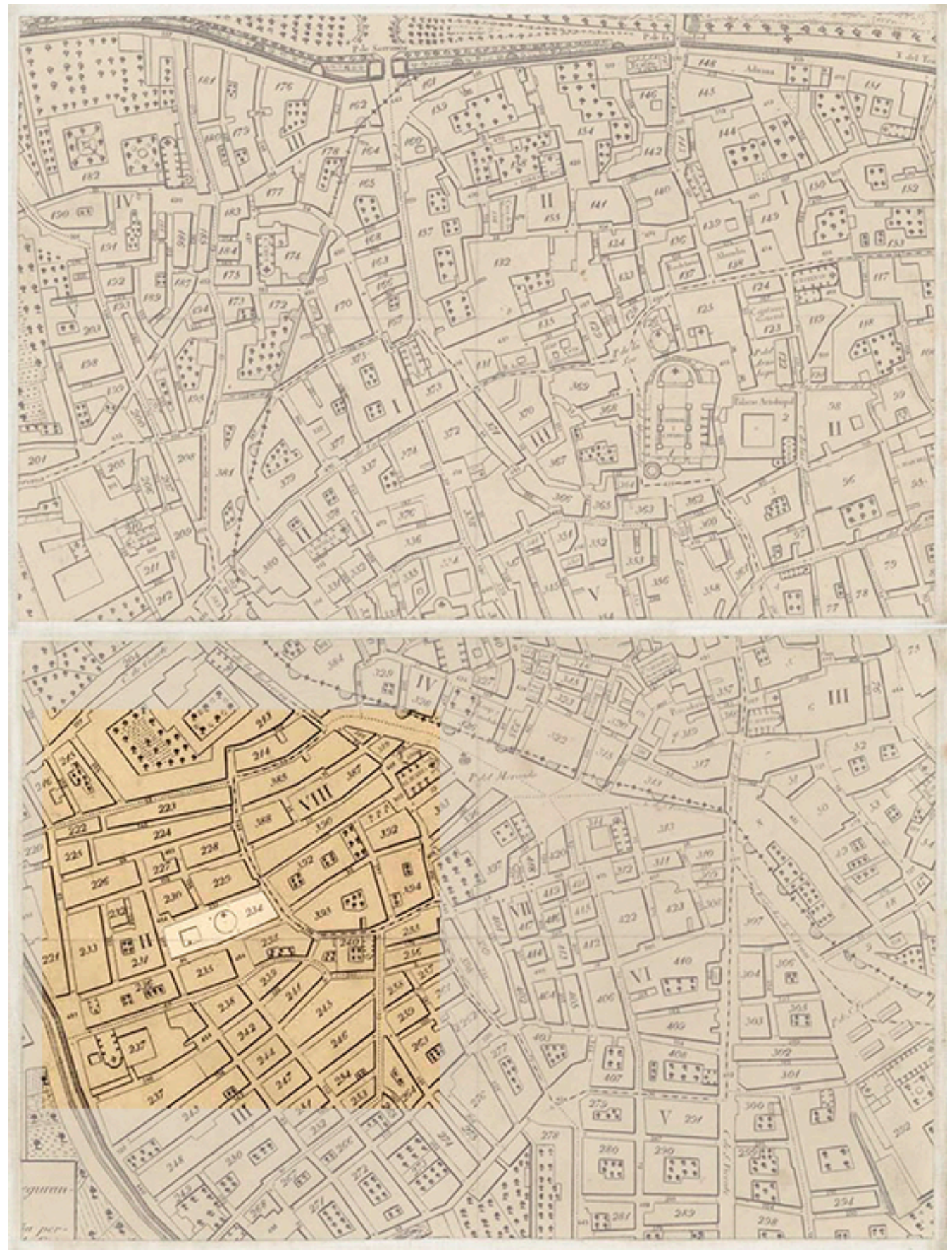

Fig. 7 Detail of the Plano geométrico de la Ciudad de Valencia llamada del Cid showing the dome. Image: (Ferrer 1831) 
It is precisely its large size and lightness which have prompted questions and controversial debates regarding its constructive technology. As we know, it is a large single-shell solid brick dome. As for the internal arrangement of these bricks, not much is known, although repeated mentions are made of the possible existence of metal rings over the parallel lines direction and to metal ribs in the meridian lines direction, arranged according to the ten sectors described above. Benito Bails, a great connoisseur of construction systems, in spite of recognizing the use of iron, did not recommend it for buildings or domes, meaning that its use is simply attributed to project errors:

Podemos, pues, sentar como regla general, que en las fábricas, particularmente si han de durar algún tiempo, se debe escusar gastar hierro, á no ser en algún lance forzoso, porque los Arquitectos solo apelan á este recurso quando conocen que se han equivocado, ó que no han dado á los estribos la competente resistencia.

(We can, therefore, lay down as a general rule, that in constructions, particularly if they are to last for some time, it is necessary to avoid iron, unless it is in some forced set, since the architects only appeal to this resource when they know that they have mistaken, or that they have not provided the stirrups with the necessary resistance” (Bails 1796: 161, our trans.).

However, Zacarés describes in detail the work of the Escuelas Pías, with special attention being paid at the metallic elements of its dome (Zacarés 1849: 497-498), which he describes as twenty bars in the meridians and several metal rings in the parallels. Similarly, Rafael Guastavino published a section of the Escuelas Pías dome where he notes "Brick Dome with Iron Rings” (Guastavino 1893: 39).

These two descriptions of the dome have caused that the presence of metal elements is commonly accepted among historians of the Valencian architecture, such as the prestigious Joaquín Bérchez Gómez. However, architect Rafael Soler states that, although these metallic elements appear in the project, it does not guarantee that they were really placed, since there are other things that were projected and finally not executed (Soler Verdú 1996: 493). In addition, Soler has acted on the dome and to date has not found evidence of their presence, so he holds a reasonable doubt, waiting for new data.

\section{Analysis of the Dome's Lesions}

The building and the church of the Escuelas Pías have suffered various damage brought on by the passing of the years. Many interventions have taken place, giving rise to different solutions that have kept the ensemble in good condition until today. In the school, it is worth highlighting two actions carried out on its main façade: on Calle de los Carniceros, and in its back façade, looking out to the school's courtyard. Both interventions were carried out by architect Rafael Soler. However, among all the constructions of the ensemble, the great blue glazed-tile dome of its church stands out. This dome presents some lesions that are perfectly visible from the inside in the form of cracks that run along the meridian direction, even affecting part of the drum. Likewise, there are areas with widespread chipping over its inner surface (Fig. 8). 


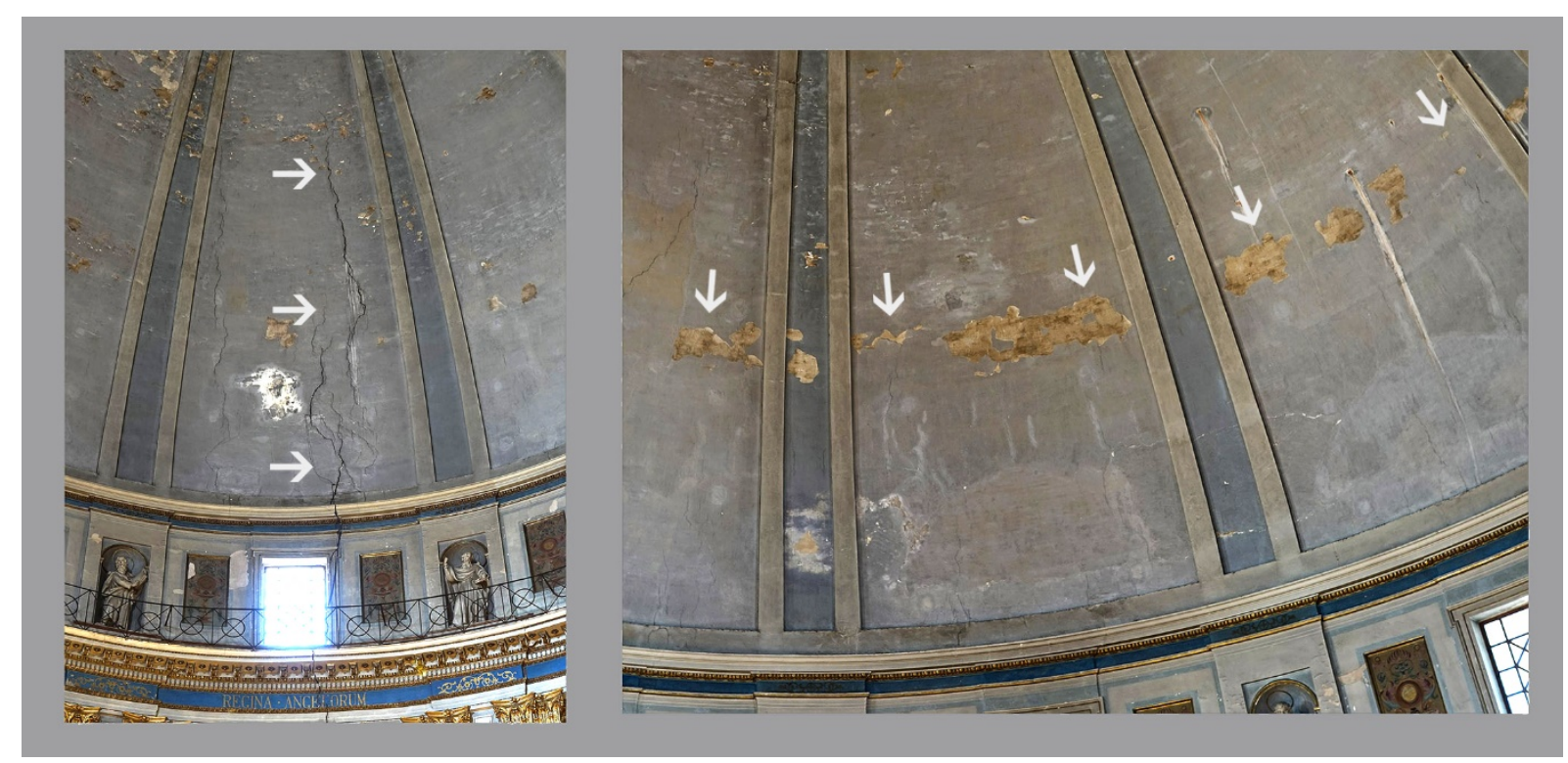

Fig. 8 Dome damage. Meridian cracks (left) and lines of chipping forming a ring (right). Source: Rodríguez-Navarro \& Gil-Piqueras

As we have already mentioned, this great dome represents a technological and constructive challenge of the third quarter of the eighteenth century, which has always favoured a certain alarmism regarding the actual stability of the city's largest dome. This fact has promoted the realization of different non-destructive analysis for the improved knowledge of its constructive and structural functioning.

Thus, prior to initiating our data collection, we compiled those studies that had been carried out previously, and which as far as we know were fundamentally two; a graphic survey and a structural study (Soler 1993).

The graphic survey was carried out by a discontinuous measurement procedure, that is, in a point by point manner, and was assisted by topographic support carried out through the use of a theodolite. The result was a vector survey of high-dimensional quality, but with the intrinsic need for idealization. In such a way, the dome shown is a slightly pointed hemisphere, providing valuable information on the project's morphology but without contributing information related to the analysis of damage due to possible settlement, movements or defects of execution.

Likewise, the study carried out on its structural behaviour shows a correct behaviour and provides guarantees on its stability, since all the structural reinforcements are placed in the correct areas. However, without questioning this work, it must also be said that this study takes as a model the aforementioned ideal so that, in principle, it would guarantee the stability of the design, and not the current situation, nearly 250 years later.

In this kind of historical construction, another very useful source of information is usually the graphic or photographic documentation obtained during maintenance or consolidation works. According to the information provided, the works on the dome have been concentrated in two areas; the lantern and the roofing tile cover. In the lantern, it may be observed that the windows have been walled with brickwork. In a first phase, they were walled using perforated brick, allowing the lantern to continue ventilating through these holes. However, later on, this 
new enclosure was coated with cement mortar, apparently to prevent the entry of rainwater. Regarding the tile roof, the works performed have been restricted to its maintenance, that is, the replacement of broken or fallen roofing tiles, either isolated or affecting larger areas. Currently we have observed a poor state of these in some areas, probably due to the damage caused by the workers who walled the lantern windows.

In principle, closing the lantern prevents the correct hygrothermal performance of the dome, that is, it makes it difficult to compensate the differences in temperature and humidity between the outer and inner part of the dome. This fact can favour the tensions of building materials and the appearance of condensations.

In the absence of non-destructive testing, and with only these approximations to the state of the dome, no other data were available for analysis, attributing as a main reason for the damage, the great thermal amplitude that is reached in Valencia, that is to say, the substantial temperature changes that can be registered within the same day, along with the high ratio between the dome's height and its section, resulting in an extreme thinness.

\section{Exploratory Methodology Based on Graphic Surveying}

The church had never been subjected to a continuous high-precision graphic survey, that is, a graphic survey of its surfaces, due to the scarce historical graphic documentation available (Murphy et al. 2008). Nowadays, we have at our disposal two methods to carry it out: 3D laser scanning and SfM photogrammetry (Verdiani 2019: 95). In this case, in order not only to obtain a metric survey, but also to gain whichever information related to its damage it can provide, it was determined to perform the graphic survey using both methodologies.

\section{a) 3D laser scanning survey}

For the 3D laser scanning survey, a high-resolution data capture system (High-Definition Survey (HDS)) has been employed, using a Terrestrial Laser Scanner (TLS), equipped with an internal camera that fulfils the function of assigning RGB information to each of the measured points, providing more realistic and intuitive models. The scanner used is a Leica ScanStation $\mathrm{P} 40$, an instrument with a time-of-flight measurement system capable of acquiring up to $1,000,000$ points/second, with a range of accuracy of single measurement of $1.2 \mathrm{~mm}+10 \mathrm{ppm}$ over the entire range. During the measurement process, this scanner has a horizontal and a vertical field-of-view of $360^{\circ}$ and $290^{\circ}$, respectively (Fig. 9).

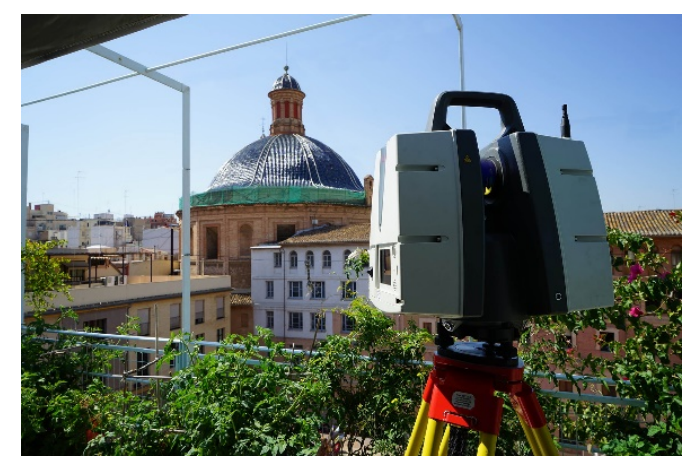

Fig. 9 Data collection from nearby buildings by means of a 3D laser scanner. Source: RodríguezNavarro \& Gil-Piqueras 
In total, 54 scans were taken from different sites, located both inside and outside the dome. In this way, we have managed to cover its entire dimension, taking special care not to leave unscanned areas. The choice of scan positions was conditioned by the complete visibility of the dome and the search for common points between the interior and exterior captures, necessary to join the scans together. The merging of the different point clouds has resulted in a complete three-dimensional modelling of the dome and the surrounding buildings.

The measurement resolution used, equivalent to the density of points captured, depends mainly on factors such as the distance between the scanner and the object to be scanned, the obliqueness in the measurement or the available capture time. In this sense, the use of high resolutions $(6.3 \mathrm{~mm}$. at $10 \mathrm{~m})$ for distances greater than $20 \mathrm{~m}$. and medium resolutions $(12.3$ $\mathrm{mm}$. at $10 \mathrm{~m}$.) for distances lower than $20 \mathrm{~m}$. was considered to be optimal. At this point, it should be taken into account that the total density of the model is not the density of a scan but the result of merging the different scans; thus, the final resolution is considerably higher than this.

After data collection, the different point clouds were registered to generate the 3D model, using the Cyclone 9.1 software. Subsequently, to establish the exact dimensions and obtain the dihedral views, the Bentley Pointools software was used.

\section{b) Photogrammetric survey}

The SfM (Structure from Motion) system was used to obtain the 3D model based on photogrammetry. This method is based on the phenomenon by which three-dimensional structures can be reconstructed from 2D images due to the changes in the appearance of the objects when the observer's point of view changes. The reliability of this methodology against 3D laser scanning has already been demonstrated (Rodríguez-Navarro 2012). In this type of restitution, the first step consists in aligning the photographs that will be used for the model's reconstruction. This work includes the calibration and correction of all images based on the EXIF data. The procedure is based on the use of the contrast of several pixels in the image as a shape, looking for homologues in all photographs and, with it, the relative positions of each camera. The set of camera positions, along with the photographs themselves, are used for the next phase, which is the geometrical construction of the model, that is, the generation of the 3D polygon mesh defining the surface of the model. Finally, a photorealistic texture can be automatically created, thus obtaining the 3D model from which the orthographic views we can extracted. On this occasion, Agisoft's Metashape software was used.

The camera used for photo modelling was a Sony $\alpha 7 \mathrm{R}$, with a 36.4 MP resolution, CMOS full-frame sensor, and ZEISS f4 lens with a 24-mm focal length. Two series of ring-shaped images were taken at an approximate distance of two meters between shots. The first one was taken from the church's ground level and the second from the drum, with a total of 82 photographs.

The photographic sequence were taken at a maximum distance of $35.2 \mathrm{~m}$. from the wall, and a distance of 1 meter approximately between shots, which guaranteed an overlap of over 80-90\%. In SfM multi-image photogrammetry the Ground Sample Distance (GSD) parameter is used as an indicator of the quality of the capture. This parameter establishes the distance 
between two consecutive pixels of the plane of the restored model. It is calculated according to the following expression:

$$
G S D=\frac{S w * H * 100}{F R * i m W}
$$

where: Sw is Camera sensor width (mm); FR is Camera focal length (mm); H is Object distance $(\mathrm{m})$; and imW is Image width (pixels).

A GSD of $0.6132 \mathrm{~cm} /$ pixel was obtained in this case with the used parameters:

\begin{tabular}{|c|c|c|}
\hline Sw & 35.9 & Sw = Camera sensor width (mm) \\
\hline Sh & 24 & Sh= Camera sensor height (mm) \\
\hline FR & 28 & FR = Camera focal length (mm) \\
\hline H & 35.2 & H = Object distance (m) \\
\hline imW & 7360 & imW = Image width (pixels) \\
\hline GSD & $\mathbf{0 . 6 1 3 2}$ & GSD = Resolution (cm/pixel) \\
\hline
\end{tabular}

\section{Discussion and Conclusions}

Both graphic surveys have been quite informative for the best knowledge of the dome. In the first place, we have focused our interest in knowing its real dimensions. Measuring on the global point cloud, we calculated that the dome has an interior span of $24.80 \mathrm{~m}$. The section of the single-shell dome is variable, having an average dimension of $0.84 \mathrm{~m}$. including the roofing tile layer, which could reach a thickness of $0.50 \mathrm{~m}$.

A first analysis of the results obtained by 3D laser scanning has revealed some deviations between the ideal and the real model. We are referring to the lantern of the dome, which as can be appreciated in Fig. 10, presents a significant partial collapse. It should be remembered that the windows of said lantern were walled using perforated brick and a cement mortar coating, so it is supporting an additional load that adds to the lantern's own weight. In consequence, the centre of gravity of the lantern's total weight is currently displaced from the geometric centre of the dome, causing an unexpected moment of inertia. In any case and in our view, the tensions that this moment of inertia can cause do not seem to be very significant if we take into account the total weight of the dome, so in principle they should be absorbed without major problems. 


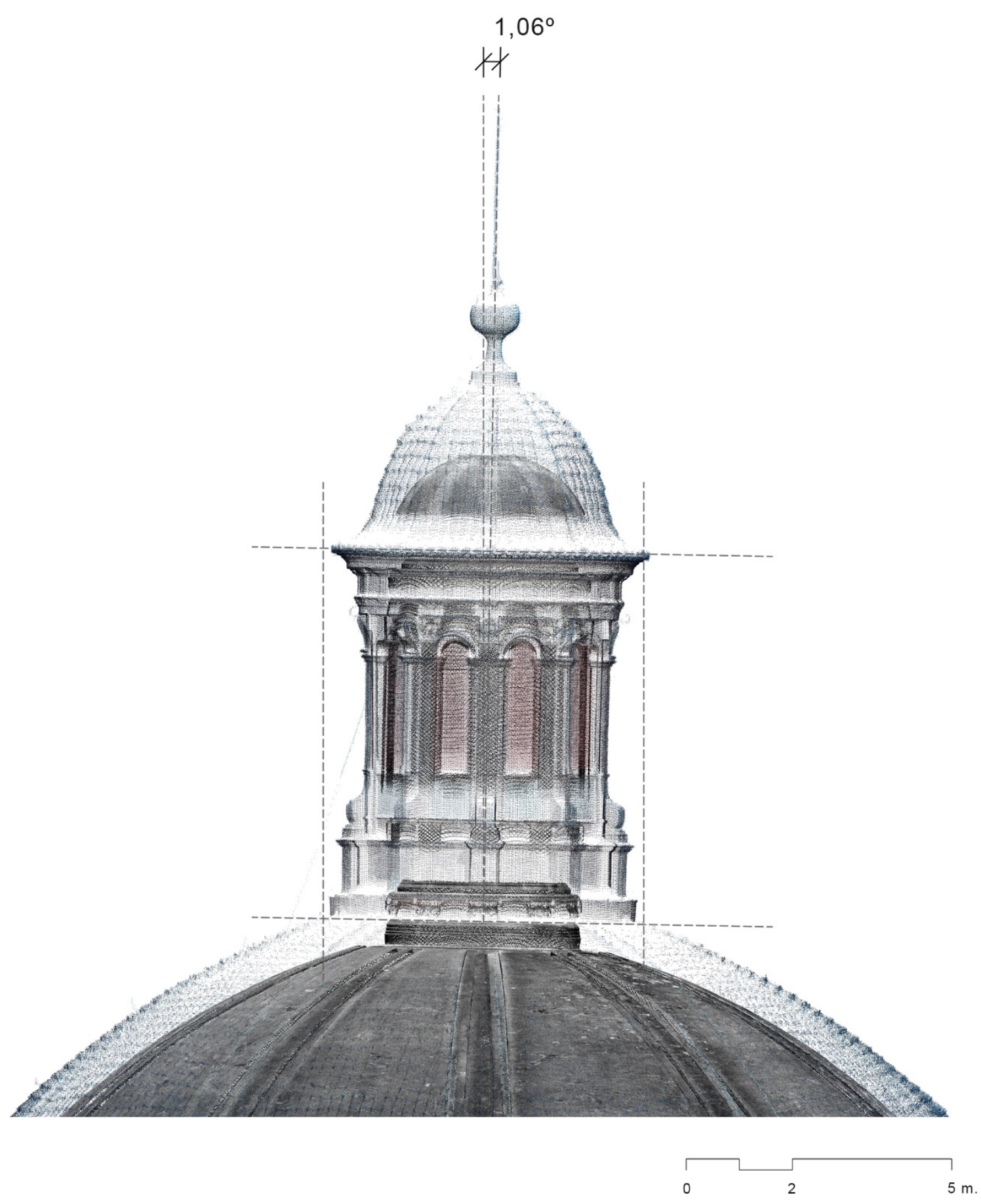

Fig. 10 Point cloud of the upper part of the dome allowing observation of the lantern's inclination.

Source: Rodríguez-Navarro \& Gil-Piqueras

From the inspection of the three-dimensional model obtained by SfM photogrammetry we also obtained new contributions, in this case for the best knowledge of this great dome, approaching the construction system used, and revealing the aforementioned controversies. The 3D model includes the texture from the photographic shots; this texture has undergone several changes in the white balance with the aim of accentuating subtle tonal changes and making all 
lesions more visible, even those that go unnoticed. The result has revealed two series of chipping, which are grouped together forming lines as perfect parallels of the dome. These lines of greater degradation than the rest of the dome's surface seem to clearly respond to the metal rings whose existence was suspected (Zacarés 1849: 497-498; Guastavino 1893: 39; Soler Verdú 1996: 493) and which, probably due to their oxidation, now manifest themselves more clearly on the surface due to the photographic method described above (Fig. 11).

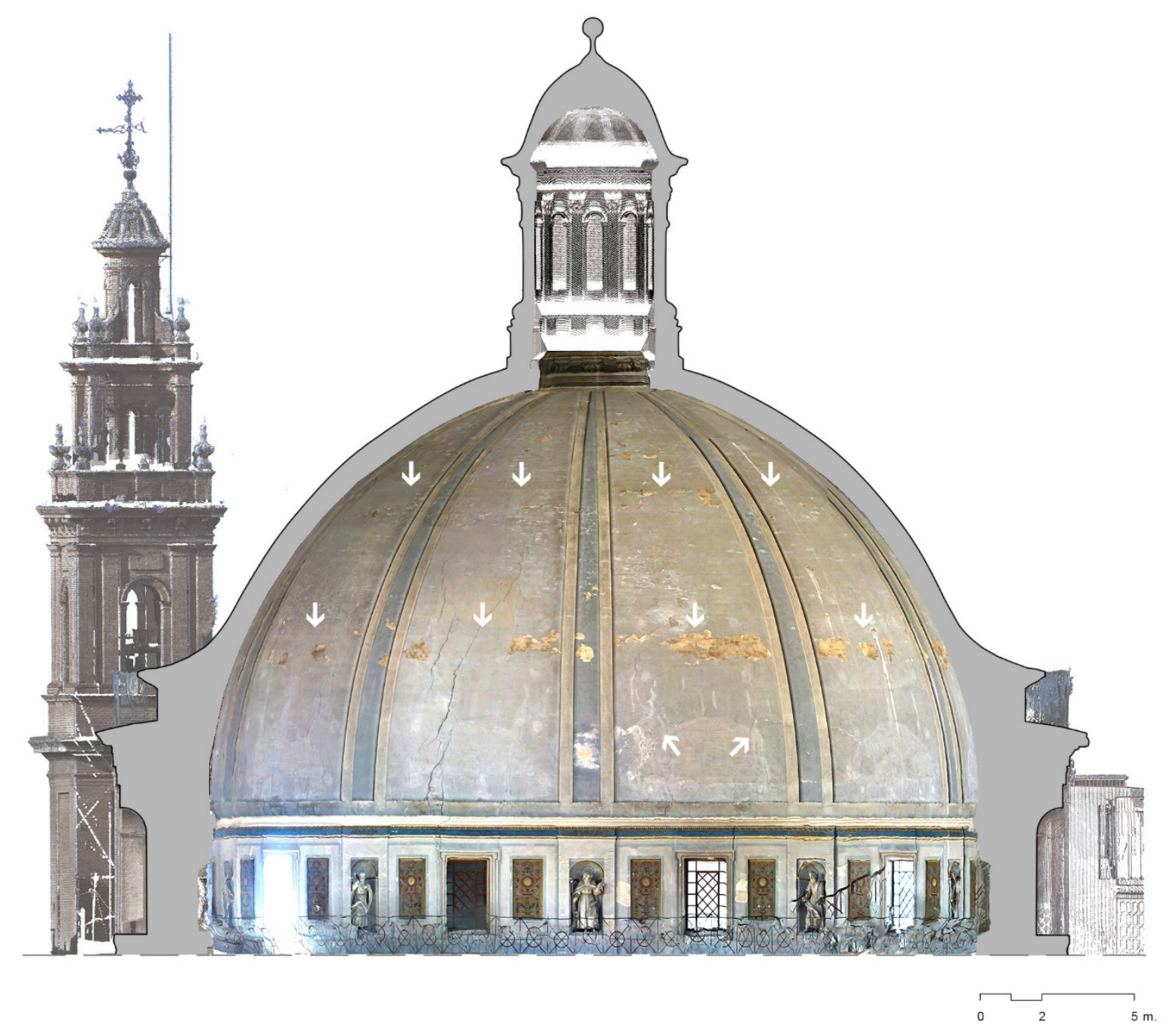

Fig. 11 Photogrammetry of the dome over the 3D laser scanning point cloud. Visualization of damage due to metal rings and presence of relieving arches. Source: Rodríguez-Navarro \& Gil-Piqueras

Finally, in the same 3D model obtained by photogrammetry, a series of relieving arches of the dome to the drum become apparent, once again inspired by the first level of the arches of the Pantheon's dome. These semi-circular arches are located between the mouldings that divide the dome into 10 sections, relieving this area in order to open a window under each of them at the level of the drum. 
We can finally conclude this work with the certainty of having advanced the knowledge of the current state of the dome and its construction system, both necessary to be able to perform restoration works. Thanks to the precision graphic survey we have been able to make new contributions, such as calculating its real dimensions, the lantern's tilt and the further knowledge of the construction system used with the incorporation of two metal rings and relieving arches, and all by means of non-destructive testing methods such as graphic surveys.

\section{Acknowledgments}

We would like to thank Professor Rafael Soler Verdú, conservation architect of the Escuelas Pías of Valencia, for all the information provided and the interesting discussions we had a chance to share with him. We would also like to thank architect Alba Soler Estrela, for entrusting us the dome surveys by means of laser scanning and photogrammetry. Likewise, we thank architects Luis Cortés Meseguer and Ricardo Perelló Roso for the information provided to prepare this article. And finally, our acknowledgment to the Escuelas Pías of Valencia for facilitating the access to its premises to carry out the graphic survey work.

\section{References}

Bails, Benito. 1796. Elementos de matemáticas. Que trata de la arquitectura civil, Tom. IX, parte 1, $2^{\mathrm{a}}$ ed. Madrid: Imprenta de la Viuda de D. Joaquín Ibarra.

Bérchez, Joaquín. 1983. Iglesia de las Escuelas Pías. In: Catálogo de Monumentos y conjuntos de la Comunidad Valenciana, vol. 2, ed. Joaquín Bérchez, 492-504. Valencia: Generalitat Valenciana, Conselleria de Cultura, Educació i Ciència.

Corbín Ferrer, José-Luis. 2001. Origen e historia de las calles del centro histórico de Valencia, vol. 1. Valencia: Fundación de Aguas de Valencia.

Cortés Meseguer, Luis. 2018. La reforma neóclasica de la Catedral de Valencia: diseño y ejecución. In: Thesaurus Ecclesiae, Thesaurus Mundi. Las Jornadas sobre el Patrimonio Cultural de la Iglesia, Xàtiva, 2016, ed. J. I. Pérez Giménez, 67-92. Xátiva: Iglesia Colegial Basílica de Santa María de Xàtiva.

Ferrer, Francisco. 1831. Plano geométrico de la ciudad de Valencia llamada del Cid. Dedicado a la Real Sociedad Económica de la misma por D. Francisco Ferrer Académico de mérito en la clase de Arquitectura de la Real de Nobles Artes de S. Carlos, AÑO 1831. Biblioteca Valenciana Digital. https://bv2.gva.es/es/consulta/registro.do?id=7310.

Fontana, Carlo. 1694. Il Tempio Vaticano e sua origine, 399-401. Rome: Nella Stamparia di Gio. Francesco Buagni.

Guastavino, Rafael. 1893. Essay on the theory and history of cohesive construction, applied especially to the timbrel vault, $2^{\mathrm{a}}$ ed. Boston: Ticknor and company.

Huerta Fernández, Santiago. 2007. Oval Domes: History, Geometry and Mechanics. Nexus Network Journal 9(2): 211-248. https://doi.org/10.1007/s00004-007-0040-3.

Montoliu Soler, Violeta. 1983. Escuelas Pías. In: Catalogo monumental de la ciudad de Valencia, ed. F. M. Garín Ortiz de Taranco, 355-356. Valencia: Caja de Ahorros de Valencia.

Murphy, Maurice, Sara Pavia, Eugene McGovern. 2015. Correlation of Laser-scan Surveys of Irish Classical Architecture with Historic Documentation from Architectural Pattern Books. In: Architecture and Mathematics from Antiquity to the Future, eds. Kim Williams and Michael J. Ostwald, vol. II, 541-550. Basel: Birkhäuser. 
Rodríguez-Navarro, Pablo. 2012. Automated Digital photogrammetry versus the systems based on active 3D sensors - La Fotogrametría Digital Automatizada frente a los sistemas basados en sensores 3D activos. Revista EGA, 20, año 17: 100-111.

Soler Verdú, Rafael. 1996. Cúpulas en la arquitectura valenciana de los siglos XVI a XVIII. In: Actas del Primer Congreso Nacional de Historia de la Construcción, eds. A. de las Casas, S. Huerta, E. Rabasa, 491-498. Madrid: I. Juan de Herrera, CEHOPU.

Soler Verdú, Rafael. 1993. Escuelas Pías Master plan. Valencia: not published.

Soler Verdú, Rafael and Alba Soler Estrela. 2015. Tipología de cúpulas tabicadas. Geometría y construcción en la Valencia del siglo XVIII. Informes de la Construcción. http://dx.doi.org/10.3989/ic.13.180.

Soler Blázquez, Víctor José. 2017. Origen y establecimiento de las Escuelas Pías en Valencia (1735-1742). Tesis Doctoral. Universidad CEU Cardenal Herrera. Valencia. https://repositorioinstitucional.ceu.es/bitstream/10637/8539/1/Origen\%20y\%20establecimi ento\%20de\%20las\%20Escuelas\%20P\%c3\%adas\%20en\%20Valencia_1735-1742.pdf

Spallone, Roberta, and Marco Vitali. 2017. Volte stellari e planteriane negli atri barocchi in Torino. Canterano: Aracne.

Verdiani, Giorgio. 2019. Digital survey: from new technology to everyday use, a knowledge path and challenge for scholars. EGE Revista de Expresión Gráfica en la Edificación 11: 94105.

Zacarés, José María. 1849. Antigüedades y bellezas de Valencia. Colegio Andresiano e Iglesia de las Escuelas Pías. Revista Edetana, 369-371, 401-403. Valencia: Jose Ruis. 